\title{
Importance-Performance Matrix Analysis (IPMA) to Evaluate Servicescape Fitness Consumer by Gender and Age
}

\author{
Jerónimo García-Fernández ${ }^{1} \mathbb{(}$, Jesús Fernández-Gavira ${ }^{1, *}$, Antonio Jesús Sánchez-Oliver ${ }^{2} \mathbb{D}$,

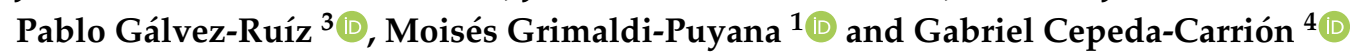 \\ 1 Department of Physical Education and Sport, Universidad de Sevilla, 41013 Sevilla, Spain; \\ jeronimo@us.es (J.G.-F.); mgrimaldi@us.es (M.G.-P.) \\ 2 Departamento de Motricidad Humana y Rendimiento Deportivo, Universidad de Sevilla, \\ 41013 Sevilla, Spain; sanchezoliver@us.es \\ 3 Máster Universitario en Gestión Deportiva, Universidad Internacional de Valencia, 46002 Valencia, Spain; \\ pablo.galvez@campusviu.es \\ 4 Management and Marketing Department, Universidad de Sevilla, 41018 Sevilla, Spain; gabi@us.es \\ * Correspondence: jesusfgavira@us.es
}

Received: 20 July 2020; Accepted: 4 September 2020; Published: 9 September 2020

check for updates

\begin{abstract}
The fitness sector has always been linked to the analysis of the loyalty of its consumers. Different studies have shown the importance of sports service and human resources for greater customer loyalty. However, few works have studied how the physical environment or servicescape influences the behavior of consumers in fitness centers based on gender and age. Therefore, the objective of the study was to analyze the relationship between servicescape and the loyalty of fitness center consumers, analyzing through the Importance-Performance Matrix Analysis (IPMA) what the aspects to improve according to gender and age are. The sample was 10,368 fitness center customers (5864 women and 4504 men). After the IPMA, it was concluded that the main improvement margins in general in fitness centers were the equipment and the facility condition, and the facility layout. In turn, in relation to gender and age, the aspects with room for improvement were to a greater extent for equipment and facility condition in women over 21 years of age, and in facility layout for women between 21 and 40 years old and 51-60 years old. Regarding men, the aspects with the highest performance margins were the equipment and facility condition in all the age groups, the facility layout in men up to 50 years old, and the signage in men up to 40 years old and from 51 to 60 years old.
\end{abstract}

Keywords: importance-performance matrix analysis (IPMA); fitness industry; sport consumer; servicescape; gender; age

\section{Introduction}

The fitness sector is a rapidly growing industry [1]. According to the International Health, Racquet, and Sportsclub Association [2], there has been a significant growth in the last decade in terms of the number of gyms, fitness clubs, and other fitness centers, as well as the amount of people who join them. Although at a slower rate than in previous years, the fitness market continues to grow and be consolidated in Europe and Spain [3]. Precisely, the Spanish fitness sector in 2019 increased its membership by $3.3 \%$, with a penetration of this activity of $11.7 \%$. This has meant 2.352 million euros in terms of income, meaning the fifth position in the ranking of European countries in this regard and continuing its upward trend in the fitness sector. Observing the evolution of recent years, it can be said that the Spanish fitness sector is in a state of maturity, but still with room for growth [3]. 
Despite the growth of the fitness industry, the current situation in the sector makes stakeholders increasingly concerned about the good performance of their organizations in order to determine priorities and/or needs, and to formulate better strategies [4,5]. In this way, the fitness industry immersed in the service sector, has been focused on the value proposition of its offer, which is ultimately intangible. Yet, tangible aspects such as the space where the sports service is produced cannot be hidden and could have a strong effect on the perceptions of consumers themselves [6]. From this perspective, the servicescape concept emerges, which is understood as "the physical environment that impacts the behavior of customers and employees in service organizations" [7]. In fact, it is understood that both customers and employees perceive the physical environment through a variety of objective environmental factors and that both groups can respond cognitively, emotionally, and physiologically to this tangible environment [6]. Precisely, the fitness sector has realized the importance of the physical environment to improve the quality of its service, having hardly analyzed the servicescape in fitness centers [8,9].

Studying this is essential in fitness centers, since their knowledge and their proposals for improvement can have an impact on the increase in the number of users and, above all, on customer loyalty [8]. Therefore, if the consumer perceives the aspects of servicescape as positive, they will have a greater chance of being a loyal customer [10]. In turn, gender or age could be presented as determining variables in the perception of the different aspects that make up the servicescape, due to their differences in the perception of sports services [11,12].

In light of these considerations, one of the most useful tools for directors and managers is the importance-performance analysis, which starts from the modeling of partial least squares structural equations (PLS-SEM). This analysis, called importance-performance matrix analysis (IPMA) [13], is a useful technique to identify the areas of improvement that management activities must address [14], and which has hardly been used in studies of the fitness sector. Therefore, this analysis would help to understand the influence of servicescape on consumer loyalty and would identify those aspects with room for improvement by gender and age. The findings would help managers to propose improvement actions segmented by gender and age to achieve more loyal consumers.

Based on the above and despite the high customer turnover in the fitness industry and its growing global importance [4], there is a research gap regarding the relationship between servicescape and consumer loyalty in fitness centers. Similarly, although there are studies in the fitness sector that have analyzed the importance and performance of fitness consumer [12], there is also a breach in the sports management literature analyzing through IPMA the variables servicescape and loyalty according to gender and age. Based on these limitations in the academic literature, the research questions are: Is there a relationship between servicescape and consumer loyalty in fitness centers? Moreover, what are the aspects of servicescape that can be improved in fitness centers from the point of view of the consumers' gender and age? Based on the comments and answering to the research questions, this study aims to analyze the relationship between servicescape and the consumers' loyalty of fitness center, analyzing through the IPMA what the aspects to improve according to gender and age are.

\section{Theoretical Foundation}

\subsection{Servicescape and Its Relationship with Consumer Loyalty in Fitness Centers}

Servicescape is considered the design of service environments made up of environmental dimensions such as space and its function, signs, symbols, instruments, and the people who interact in the service delivery environment. In this sense, the concept understands space as holistic, understood as a whole [15]. That is, "everything that is physically present around the consumer during the service encounter transaction" [16]. In fact, servicescape is a vital concept to know and intervene in customer behavior. Hence, it is considered a facilitator that adds or hinders the behavior of both employees and customers when carrying out their activities in the service sector $[17,18]$. For this reason, service providers must offer environments that enhance consumer experiences and facilitate operational ease and promote overall business efficiency [19]. 
The study of the servicescape has been carried out in different contexts, such as banks [20], healthcare settings [17,21]; game rooms [22,23], travel [24] and sports environment [25,26]. Although there are several articles focused on the sports context, few have focused on examining the servicescape in the environment of fitness centers $[8,9]$. Thus, since fitness centers are highly dependent on their physical environment, it is essential to understand the impact of the physical environment on users and their behavior, obtaining a better understanding of environmental concepts and what factors could influence consumers' perceptions.

If these perceptions had a positive influence on customer behavior, consumer loyalty would be increased. This loyalty is desired by fitness centers which, due to continuous competition, has led them to find ways of differentiating themselves to retain existing members and attract new ones [1]. A solution could be linked to servicescape. In fact, Chang (2016) examined a service firm and identified a positive relationship between the servicescape and customers' behavioral intentions [27]. Others, such as Madzharov, Block and Morrin (2015), also examined how ambient scents affect consumers' perceptions and feelings and, subsequently, their purchase intention [28]. Recently, the study of Tran, Dang and Tournois (2020) has revealed the positive relationship between servicescape and consumer loyalty in coffee stores [29], as also indicated by the studies of Lee, Fu and Tsai (2019) and, Rai and Anirvinna (2019) [30,31]. Regarding studies that have analyzed both variables in the sports sector, Hightower, Brady, and Baker (2002) showed that there was a positive relationship in sporting event customers [32]. In particular in the fitness sector, only one study is found that has confirmed the positive relationship between servicescape and loyalty [8], although the study had the limitations of a small sample and a limited number of servicescape dimensions.

For all this, taking into account that loyalty is one of the main objectives of the fitness sector [33], different studies have analyzed what could be the variables that would influence customer loyalty in the fitness sector [34-36]. Nevertheless, although the literature has shown that there is a positive relationship between servicescape and consumer loyalty, there is a gap in the sports management literature that has examined the relationship between servicescape and loyalty.

\subsection{Differences in the Perception of Sports Services by Gender and Age}

Providing information to sports organizations about the relative proportion of users with a certain profile, what their sociodemographic characteristics are, as well as their perception and consumer loyalty, allows improving the design of the service offer and therefore improving consumer satisfaction [11].

Despite the existence of research in the field of fitness centers on consumer perception [37-39], most is focused on demonstrating the relationship between antecedent variables of fidelity, without having examined whether these relationships differ according to gender and age, even though they are extremely important variables [11].

Thus, although there are few contributions in this regard, some studies have shown that women have more positive perceptions and that they in turn have better fidelity indexes [40-42]. Notwithstanding, recent studies, such as that by León-Quismondo et al. (2020), have indicated that dissatisfaction was greater in women [12].

On the other hand, age is one of the sociodemographic variables that can most condition the behavior or perception of clients in fitness centers. The large number of sports services and types of clients has generated the need to carry out studies that help focus an offer according to the existing demand in the fitness centers $[43,44]$. Specifically, studies such as that of Yu et al. (2014) point out that age is directly related to the importance given to both the type of physical activity that is practiced in these centers and the aspects that are important for these people during their consumption [45]. For example, older people have a greater inclination for activities that provide them with healthy benefits with which to face their day-to-day life compared to younger people, whose centers of interest are more varied, challenging health with exercise that will allow them to achieve a more esthetic body [46,47]. For this reason, directing the marketing strategy toward one public or the other, or achieving loyalty to both, are very delicate and important decisions that managers must face in 
their professional performance. In fact, perhaps due to the orientation that each age group has to physical activity, it has been shown that older people give less importance to superfluous aspects of the facilities, compared to other age groups (young and young adults) who do [47]. Finally, almost all the population groups agree on the importance of having pleasant monitors and the accessibility of the center itself as fundamental factors in fidelity $[47,48]$.

\subsection{Important-Performance Matrix Analysis}

Strategic management of service perceptions and the physical environment of sports spaces are very important for success in sports organizations [49]. For this reason, as has been shown, studies analyzing consumer perceptions in the fitness industry are increasingly more frequent $[1,12]$.

One of the tools to assess consumer perceptions and position where managers should direct their efforts is the importance-valuation analysis (IPA), published by Martilla and James (1977) [14]. In fact, in the academic literature on sport management, there are some studies that have used it, providing what aspects must be improved for a better service $[12,50,51]$. The simplicity of its use and its applicability to explain customer satisfaction and suggest management strategies on how to prioritize resources makes this methodology very attractive for use in sports management [52]. Despite its simplicity and application, the IPA analysis offers a series of shortcomings that question its validity and usefulness due to the lack of standard criteria, along with conceptual and methodological issues $[13,53]$.

For this reason, looking for an approach from a more global perspective, the importance-performance matrix analysis (IPMA) emerges. This analysis can allow directors and managers to improve their management strategies, since it points out the main factors that require an immediate response [54]. The IPMA allows for prioritizing constructs to improve a certain target construct, identifying the most important areas for specific actions. The findings provided by the IPMA are important in practical studies that identify the different impacts that certain dimensions of the construct have on the phenomena [13]. The decision to apply this technique is supported by its usefulness in other sectors (Table 1).

Table 1. Importance-Performance Matrix Analysis (IPMA) studies.

\begin{tabular}{|c|c|c|c|}
\hline Authors & Sector/Context & Principal Findings Related & Sample \\
\hline Tailab [55] & Bank & $\begin{array}{l}\text { The study indicates that managers who } \\
\text { use the IPMA to prioritize their financial } \\
\text { decisions will obtain useful conceptual } \\
\text { insights and are unlikely to be misled. }\end{array}$ & 140 banks \\
\hline Ting, Yahya \& Tan [56] & Education & $\begin{array}{l}\text { The IPMA shows that the importance } \\
\text { and performance of domain knowledge } \\
\text { are high in contributing to sustainability } \\
\text { entrepreneurship. }\end{array}$ & 121 students \\
\hline Ebrahimi, Hajmohammadi \& Tan [57] & Tourism & $\begin{array}{l}\text { The IPMA indicates that place image } \\
\text { had the highest importance, but the } \\
\text { lowest performance. }\end{array}$ & 135 users \\
\hline Wook, Ismail \& Yusop [58] & Education & $\begin{array}{l}\text { The findings revealed through the IPMA } \\
\text { that perceived usefulness is the most } \\
\text { important antecedent, followed by } \\
\text { perceived ease of use, and optimism. }\end{array}$ & 211 students \\
\hline Groß [59] & Mobile & $\begin{array}{l}\text { Thanks to the IPMA, this study provides } \\
\text { new insights into the acceptance and } \\
\text { profile of m-shoppers. }\end{array}$ & 734 customers \\
\hline Palos-Sánchez, Martin-Velicia \& Saura [60] & Internet users & $\begin{array}{l}\text { The IPMA showed the most important } \\
\text { attributes for Internet search engine } \\
\text { developers. }\end{array}$ & 445 users \\
\hline Carranza, Díaz \& Martín-Consuegra [61] & Restaurants & $\begin{array}{l}\text { The IPMA indicate that service quality is } \\
\text { one of the three most-valued attributes } \\
\text { among those examined in fast-food } \\
\text { restaurants studies. }\end{array}$ & 456 customers \\
\hline $\begin{array}{l}\text { Reyes-Menéndez, Palos-Sánchez, Saura \& } \\
\text { Martín-Velicia [62] }\end{array}$ & Restaurants companies & $\begin{array}{l}\text { The IPMA indicated that Wi-Fi has the } \\
\text { highest valuation, although it is the one } \\
\text { that obtains the least performance. It is } \\
\text { in this construct that improvements in } \\
\text { performance must be made. }\end{array}$ & 117 customers \\
\hline
\end{tabular}


Table 1. Cont.

\begin{tabular}{cll}
\hline Authors & Sector/Context & \multicolumn{1}{c}{ Principal Findings Related } \\
\hline Ramayah, Chiun, Rouibah \& May [63] & Online banking & $\begin{array}{l}\text { The IPMA identified that the two most } \\
\text { important variables in the use of Internet } \\
\text { banking are perceived ease of use and } \\
\text { perceived ease of use. }\end{array}$ \\
\hline Rigdon, Ringle, Sarstedt \& Gudergan [64] & Utilities and hotels customers & $\begin{array}{l}\text { The IPMA illustrates differences between } \\
\text { three segments of customers and } \\
\text { provides the basis for managerial } \\
\text { implications. }\end{array}$ \\
\hline
\end{tabular}

In addition, its application is based on three motivations: IPMA facilitates more rigorous management decision making (1), IPMA is a powerful tool that can help managers set better priorities and better allocate scarce resources (2), and IPMA has guidelines for performance evaluation that serve both a company and the people who invest in it (3) [65]. In other words, IPMA provides a better understanding of where management should focus its attention. However, although IPMA has been used in different sectors helping with the findings to better management [13], so far it has not been applied in the fitness sector.

Based on the previous literature and responding to the objectives of the study, Figure 1 exemplifies the theoretical framework.

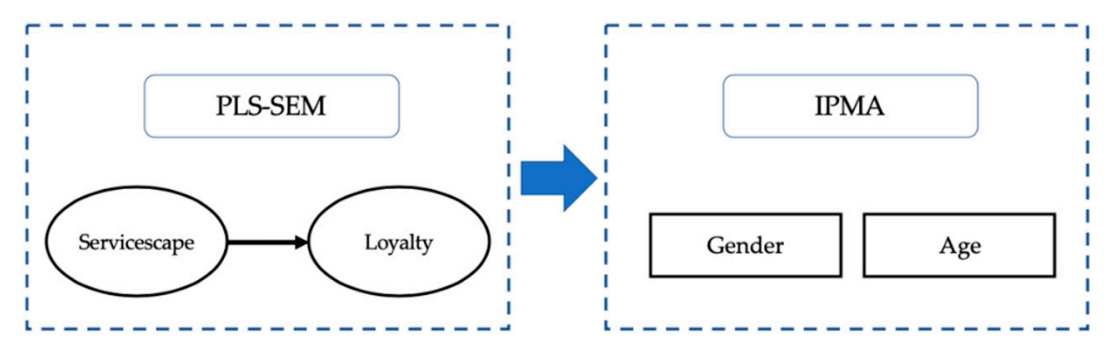

Figure 1. Theoretical framework of the study. IMPA: Importance-Performance Matrix Analysis; PLS-SEM: Partial Least Squares Structural Equations.

\section{Materials and Methods}

\subsection{Participants}

Participation was completely voluntary. We collected data for this study by using the convenience sampling method from November 2018 to March 2019. We distributed forms to 56 low-cost Spanish fitness centers. After describing the study's purpose and significance, the people who agreed to take part completed the survey. The sample was 10,368 fitness center customers. $56.55 \%$ of the respondents $(n=5864)$ were women and $43.44 \%(n=4504)$ were men. In terms of age, $3.74 \%(n=388)$ were less than 20 years old, $26.82 \%(n=2781)$ between 21 to 30 years old, $28.65 \%(n=2970)$ were 31 to 40 years old, $26.52 \%(n=2750)$ were 41 to 50 years old, $11.27 \%(n=1168)$ were 51 to 60 years old, and $3.00 \%$ $(n=311)$ were aged over 60 years. In terms of period of time the respondents had been enrolled and had exercised at the center, $46.1 \%(n=4789)$ of the participants had been enrolled for less than a year, $25.7 \%(n=2668)$ had been enrolled for more than a year and less than two years, and $27.2 \%(n=2911)$ had been enrolled for more than two years. Table 2 shows data from the sample regarding weekly frequency, previous fitness experience, and training prescription. 
Table 2. Sample characteristics.

\begin{tabular}{|c|c|c|c|c|c|c|c|}
\hline \multirow{2}{*}{ Question } & \multirow{2}{*}{ Answer } & \multicolumn{2}{|c|}{ Women } & \multicolumn{2}{|c|}{ Men } & \multicolumn{2}{|c|}{ Total } \\
\hline & & $n$ & $\%$ & $n$ & $\%$ & $n$ & $\%$ \\
\hline \multirow{6}{*}{ Weekly frequency } & Less than 1 time/week & 149 & $2.54 \%$ & 100 & $2.22 \%$ & 249 & $2.40 \%$ \\
\hline & Once/week & 242 & $4.13 \%$ & 143 & $3.17 \%$ & 385 & $3.71 \%$ \\
\hline & Twice/week & 1369 & $23.35 \%$ & 646 & $14.34 \%$ & 2015 & $19.43 \%$ \\
\hline & Three times/week & 2423 & $41.32 \%$ & 1813 & $40.25 \%$ & 4236 & $40.86 \%$ \\
\hline & Four more times/week & 1681 & $28.67 \%$ & 1802 & $40.01 \%$ & 3483 & $33.59 \%$ \\
\hline & Total & 5864 & $100.00 \%$ & 4504 & $100.00 \%$ & 10,368 & $100.00 \%$ \\
\hline \multirow{4}{*}{ Previous fitness experience } & No previous experience & 1558 & $26.57 \%$ & 899 & $19.96 \%$ & 2457 & $23.70 \%$ \\
\hline & Yes, in the current fitness center & 259 & $4.42 \%$ & 187 & $4.15 \%$ & 446 & $4.30 \%$ \\
\hline & Yes, in another fitness center & 4047 & $69.01 \%$ & 3418 & $75.89 \%$ & 7465 & $72.00 \%$ \\
\hline & Total & 5864 & $100.00 \%$ & 4504 & $100.00 \%$ & 10,368 & $100.00 \%$ \\
\hline \multirow{7}{*}{ Training prescription } & Fitness staff & 758 & $12.93 \%$ & 434 & $9.64 \%$ & 1192 & $11.50 \%$ \\
\hline & Friend & 296 & $5.05 \%$ & 203 & $4.51 \%$ & 499 & $4.81 \%$ \\
\hline & Personal trainer & 247 & $4.21 \%$ & 220 & $4.88 \%$ & 467 & $4.50 \%$ \\
\hline & Fitness App & 202 & $3.44 \%$ & 130 & $2.89 \%$ & 332 & $3.20 \%$ \\
\hline & Myself & 3840 & $65.48 \%$ & 3303 & $73.33 \%$ & 7143 & $68.89 \%$ \\
\hline & Others & 521 & $8.88 \%$ & 214 & $4.75 \%$ & 735 & $7.09 \%$ \\
\hline & Total & 5864 & $100.00 \%$ & 4504 & $100.00 \%$ & 10,368 & $100.00 \%$ \\
\hline
\end{tabular}

For this study it has not been experimented with humans or animals, nor has any vulnerable group been used in an inadequate way, all the data obtained was done through anonymous online surveys of 10,368 adults who were asked to fill out a questionnaire confidentially and to be honest with their answers, they were informed that the data obtained would be processed and published for the improvement of the fitness sector and that any personal information that they provided would be treated anonymously. To which they gave their express consent, without making it necessary for these studies to be evaluated by an external ethical committee for approval, since it has not affected in any way the ethical principles for research with humans contained in the Declaration of Helsinki.

\subsection{Instruments}

The instrument used to measure the variables of this study is a structured questionnaire. All the variables included in the study were measured with multi-item scales validated by other researchers, using a Likert scale ranging from 1 to 7. 21 items were used for servicescape were based on Kim, et al. (2016) [9]. The future intentions were measured using three items developed by Zeithaml et al. (1996) [66]. This measure has been used in other studies to measure customer loyalty in the fitness industry [35]. To adapt the study to the Spanish context, the scales of servicescape and future intentions went through a process of translation and synthesis to ensure that there were no errors of interpretation. To that end, the procedures were followed in accordance with Martín-Consuegra et al. (2015) [67]. Based on this, it is possible to compare and examine the equivalence and precision of the translated questionnaire.

\subsection{Procedure}

The chains of low-cost fitness centers with more than five sport facilities were contacted according to data from [68]. These fitness chains added a total of 213 low cost fitness centers, of which 56 low cost fitness centers decided to participate. The objectives of the study, the instrument, and the practical implications were explained to the managers of the fitness centers. Finally, five fitness center chains chose to participate, with a total of 56 fitness centers. Data collection took place after obtaining permission from the administration of each participating center. The participants gave their consent. Voluntary participation and the confidentiality of their responses was assured. Data collection was carried out through an online questionnaire using Google Forms over a period of five months. The participants took approximately $10 \mathrm{~min}$ to complete the questionnaire.

\subsection{Data Analysis}

All our measures were operationalized as composites [69,70]. Therefore, we decided in favor of using PLS-SEM as the best data analysis tool. All the composites were estimated in Mode A because 
the indicators that compound composites are correlated. Our study adopted both an exploratory and a predictive approach following Cepeda-Carrión et al. (2019) [71]. To assess models using IPMA with PLS-SEM an additional procedure implemented by SmartPLS (Version: 3.2.9; SmartPLS GmbH Company, Bönningstedt, Germany) has been established [72]. Additionally, we test our path model using the classical two step assessment proposed by Hair et al. (2014): (1) the assessment of the measurement model and (2) the assessment of the structural model [73]. In order to find out the significance of parameters, we used a bootstrap procedure [74]. Bootstrapping is a resampling procedure that is able to determine the significance of: path coefficients and the weights and loadings of the indicators for each composite (i.e., the latent variables).

To detect potential issues of common method bias (CMB) due to the instrument used, a full collinearity test based on variance inflation factors (VIFs) was carried out. According to Kock and Lynn (2012) [75] when a VIF achieves a value greater than 3.3, there would be an indication of pathological collinearity. This would warn if a model may be contaminated by CMB. The present model, with a maximum VIF of 1.02, may be considered free of CMB.

\section{Results}

According to the assessment of the measurement model, our outcomes show that the measurement model meets all the requirements suggested by Hair et al. (2014) [73]. First, the individual items are reliable because all the standardized correlation weights exceed 0.7 (Table 3), except one indicator. Yet, as this does not affect the rest of the indices of reliability and validity, we decided to keep it in our analysis. Second, because consistent measures for all the composites are greater than 0.8 (Table 4). These measures (composite reliability, Cronbach's alpha and Dijkstra-Henseler's rho) are suggested by Hair et al. (2019) [76] and Henseler et al. (2016) [77]. Furthermore, the values for average variance extracted (AVE) exceed the threshold of 0.5 (Table 4) for convergent validity. Finally, all the composites exhibit discriminant validity, since all the HTMT are below 0.85 (except one of 0.87 , below than threshold of 0.9) [78] (Table 4).

Table 3. Indicator loadings.

\begin{tabular}{|c|c|c|}
\hline Construct & Indicator & Loadings \\
\hline \multirow[t]{3}{*}{ Loyalty } & I would sign up for this fitness center if I unsubscribed (FI1) & 0.895 \\
\hline & I will make positive comments to a friend about the programs and services of this fitness center (FI2) & 0.954 \\
\hline & If you ask me, I will recommend this fitness center (FI3) & 0.967 \\
\hline Signage & The signs used are helpful (SC1) & 1 \\
\hline \multirow[t]{5}{*}{ Equipment/Facility condition } & The equipment used is always in good working condition (SC10) & 0.894 \\
\hline & Fitness center is well equipped with surrounding facilities (lounge, concession) (SC11) & 0.587 \\
\hline & The facilities and equipment are safe (SC12) & 0.877 \\
\hline & Physical facilities are well maintained (SC13) & 0.903 \\
\hline & The equipment used is of high quality (SC9) & 0.879 \\
\hline \multirow[t]{4}{*}{ Ambient Condition } & The background noise level at fitness center is acceptable (SC14) & 0.854 \\
\hline & Fitness center is kept clean (SC15) & 0.800 \\
\hline & Fitness center's atmosphere is comfortable (SC16) & 0.885 \\
\hline & The music used in fitness center makes workout environment a more enjoyable place (SC17) & 0.812 \\
\hline \multirow[t]{4}{*}{ Facility System } & Lighting levels are comfortable (SC18) & 0.789 \\
\hline & Temperature and humidity are comfortable (SC19) & 0.913 \\
\hline & Air quality is acceptable (SC20) & 0.917 \\
\hline & Heating, Ventilation and Air-conditioning (HVAC) system are well maintained (SC21) & 0.898 \\
\hline \multirow[t]{4}{*}{ Facility Layout } & Fitness center is expansive and large in scale (SC2) & 0.869 \\
\hline & Fitness center is designed for all levels of ability (SC3) & 0.838 \\
\hline & Fitness center have more than enough space for me to be comfortable (SC4) & 0.909 \\
\hline & Fitness center is designed to minimize my waiting time (SC5) & 0.860 \\
\hline \multirow[t]{3}{*}{ Facility Design } & The buildings' exterior layout is pleasing (SC6) & 0.862 \\
\hline & The buildings' interior layout is pleasing (SC7) & 0.944 \\
\hline & The buildings in fitness center are decorated in an attractive fashion (SC8) & 0.934 \\
\hline
\end{tabular}

FI: Future Intentions; SC: Servicescape. 
Table 4. Reliability and validity of construct measurement.

\begin{tabular}{cccccc}
\hline Composites & $\begin{array}{c}\text { Cronbach's } \\
\text { Alpha }(\alpha)\end{array}$ & $\begin{array}{c}\text { Dijkstra- } \\
\text { Henseler's } \\
\text { Rho }\left(\boldsymbol{\rho}_{\mathrm{A}}\right)\end{array}$ & $\begin{array}{c}\text { Composite } \\
\text { Reliability }\left(\boldsymbol{\rho}_{\mathbf{c}}\right)\end{array}$ & $\begin{array}{c}\text { Average } \\
\text { Variance } \\
\text { Extracted }\end{array}$ & $\begin{array}{c}\text { Maximum } \\
\text { HTMT }\end{array}$ \\
\hline $\begin{array}{c}\text { a } \\
\text { Ambient Condition }\end{array}$ & 0.859 & 0.870 & 0.904 & 0.703 & 0.838 \\
Facility Design & 0.901 & 0.914 & 0.938 & 0.836 & 0.741 \\
Facility Layout & 0.892 & 0.894 & 0.925 & 0.756 & 0.869 \\
Equipment/Facility Condition & 0.887 & 0.912 & 1 & 0.700 & 1 \\
Signage & 1 & 1 & 0.932 & 0.776 & 0.878 \\
Facility System & 0.902 & 0.902 & 0.957 & 0.882 & 0.839 \\
Loyalty & 0.933 & 0.938 &
\end{tabular}

As to the assessment of the structural model, Hair et al. (2014) comment that the use of bootstrapping (5000 resamples) produces standard errors and confidence intervals to assess the statistical significance of the path coefficients [73]. All the path coefficients in Table 5 and Figure 2 were significant. Our model provided R-squares of 0.55 for loyalty.

Table 5. Construct effects on endogenous variables (incl. lower and upper limits of $95 \%$ confidence interval).

\begin{tabular}{cccc}
\hline Relationships & $\begin{array}{c}\text { Original } \\
\text { Sample (O) }\end{array}$ & $\begin{array}{c}\text { Average of the } \\
\text { Sample (M) }\end{array}$ & $\mathbf{5 . 0 \%}$ \\
\hline Ambient Condition -> Loyalty & 0.258 & 0.258 & 0.282 \\
Facility Design -> Loyalty & 0.036 & 0.036 & 0.233 \\
Facility Layout -> Loyalty & 0.198 & 0.198 & 0.010 \\
Equipment/Facility Condition -> Loyalty & 0.233 & 0.233 & 0.176 \\
Signage -> Loyalty & 0.096 & 0.096 & 0.208 \\
Facility System -> Loyalty & 0.032 & 0.032 & 0.076 \\
\end{tabular}

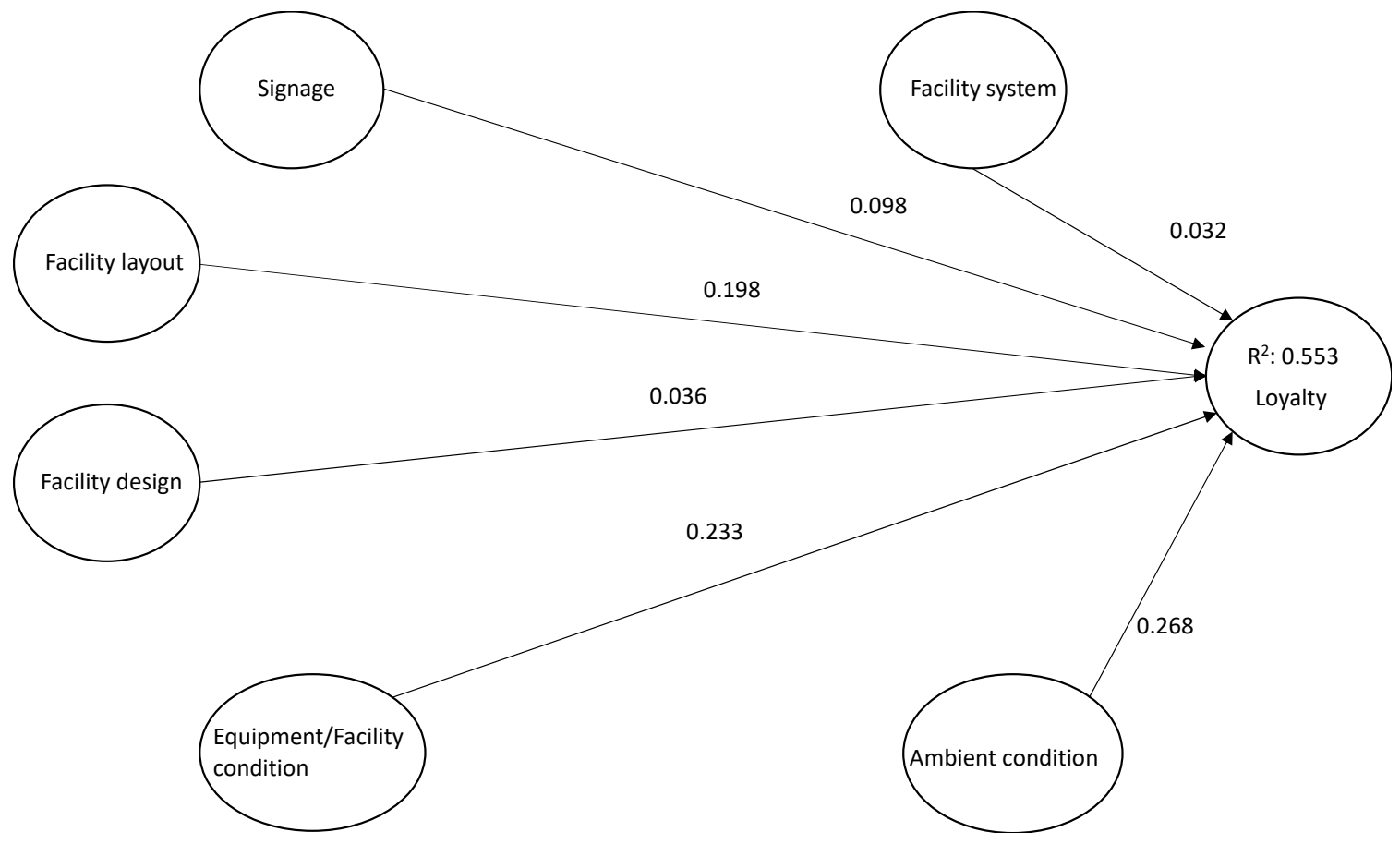

Figure 2. Relationship between constructs.

Apart from the PLS-SEM results of a structural model, IPMA helps PLS-SEM results through a four-quadrant diagram as depicted in Figure 3. The vertical axis represents the performance of the attributes from poor performance to good performance. The horizontal axis represents the perceived importance of the attributes from not very important to very important. Following Martilla and James 
(1977) [14] and Hair et al. (2019) [76], for the importance-map creation, four quadrants are illustrated as Q1 (Management is fine), Q2 (Something important that needs to be improved), Q3 (Too much performance for a non-important issue), and Q4 (it does not matter and no performance). These quadrants are delimited using the mean of performance and mean of importance reported in the table of the IPMA results.

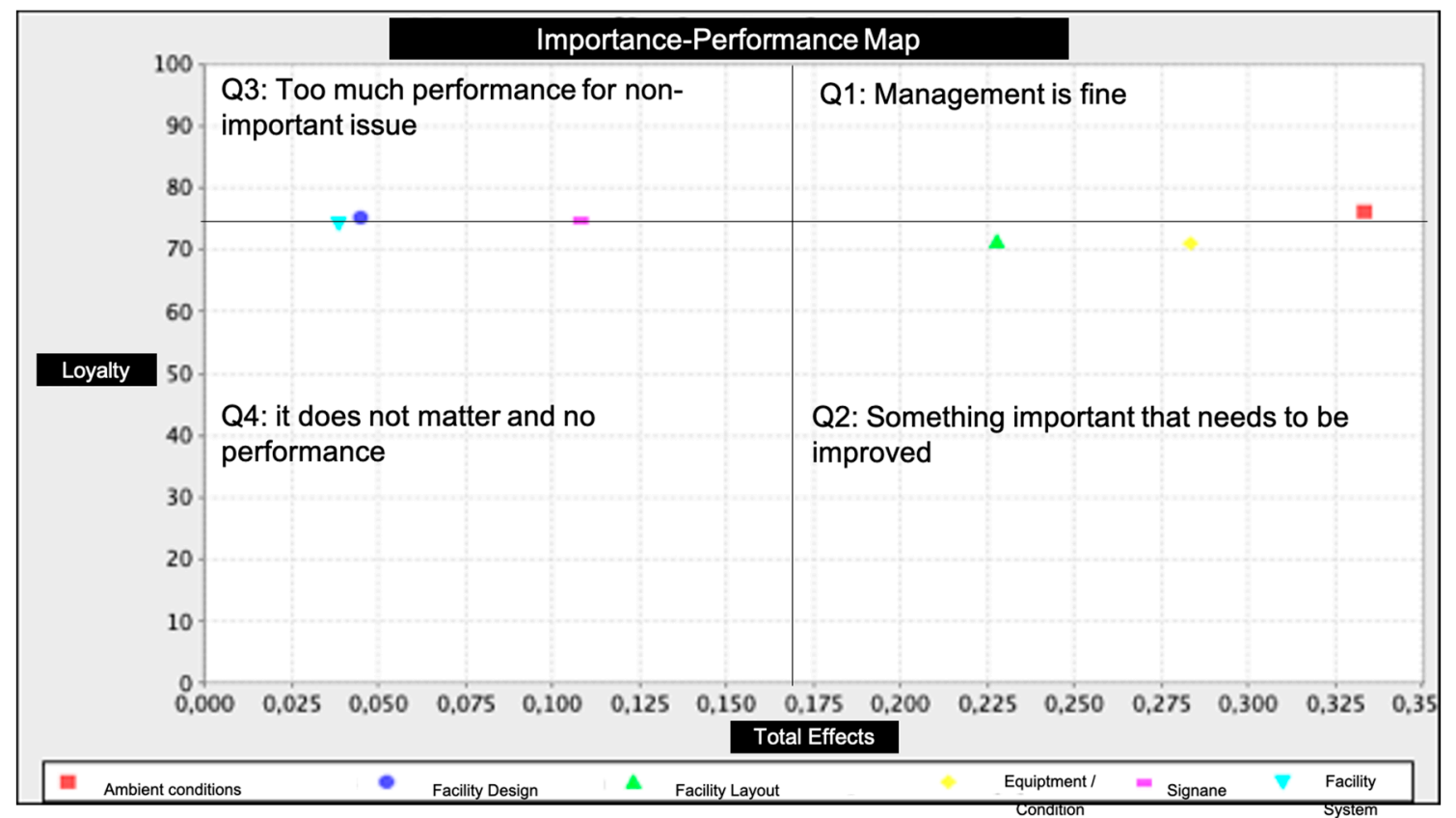

Figure 3. IPMA full data set. Note: Red: ambient condition; Strong blue: facility design; Green: facility layout; Yellow: equipment/facility condition; Pink: signage; Light blue: facility system.

The results are demonstrated in Table 6, while Figure 3 shows the 'importance-performance map' of each exogenous latent variable along with its influence on the endogenous latent variable (i.e., loyalty).

Table 6. IPMA results full data set.

\begin{tabular}{ccc}
\hline \multirow{2}{*}{ Latent Variable } & \multicolumn{2}{c}{ Loyalty } \\
\cline { 2 - 3 } & Total Effect (Importance) & Index Value (Performance) \\
\hline Ambient Condition & 0.333 & 76.082 \\
Facility Design & 0.045 & 75.254 \\
Facility Layout & 0.228 & 71.483 \\
Equipment/Facility Condition & 0.283 & 71.073 \\
Signage & 0.108 & 74.762 \\
Facility System & 0.039 & 74.108 \\
Mean & 0.173 & 73.794 \\
\hline
\end{tabular}

Additionally, we decided to distinguish between gender and age, responding to the papers' call for this special issue. Concretely, we define six age groups (i.e., $<20 ; 21-30 ; 31-40 ; 41-50 ; 51-60 ;>60$ ) and two sexes (male vs. female), which made a total of 12 categories of fitness center users. Next, we report the IPMA results for these 12 categories and their corresponding map (Table 7, Figures 4 and 5, respectively). 
Table 7. IPMA results by sex and age group.

\begin{tabular}{|c|c|c|c|c|c|c|c|c|c|c|c|c|}
\hline \multirow[t]{2}{*}{ Male } & \multicolumn{2}{|c|}{ Male $<20$} & \multicolumn{2}{|c|}{ Male 21-30 } & \multicolumn{2}{|c|}{ Male 31-40 } & \multicolumn{2}{|c|}{ Male 41-50 } & \multicolumn{2}{|c|}{ Male 51-60 } & \multicolumn{2}{|c|}{ Male $>60$} \\
\hline & I & $\mathrm{P}$ & I & $\mathrm{P}$ & I & $\mathrm{P}$ & I & $\mathrm{P}$ & I & $\mathrm{P}$ & I & $\mathrm{P}$ \\
\hline Ambient Condition & 0.379 & 79.875 & 0.406 & 75.722 & 0.295 & 73.321 & 0.465 & 72.869 & 0.278 & 72.187 & 0.053 & 74.724 \\
\hline Facility Design & -0.066 & 77.337 & -0.042 & 73.486 & 0.047 & 72.150 & 0.061 & 73.042 & 0.098 & 73.391 & 0.191 & 75.637 \\
\hline Facility Layout & 0.201 & 71.866 & 0.251 & 65.816 & 0.183 & 68.654 & 0.200 & 71.454 & 0.098 & 72.403 & 0.248 & 78.008 \\
\hline Equipment/Facility Condition & 0.253 & 76.334 & 0.271 & 69.552 & 0.299 & 68.443 & 0.220 & 68.395 & 0.333 & 67.405 & 0.435 & 71.066 \\
\hline Signage & 0.121 & 72.717 & 0.104 & 72.171 & 0.149 & 70.668 & 0.079 & 72.335 & 0.189 & 70.057 & 0.084 & 75.342 \\
\hline Facility System & 0.199 & 80.836 & 0.064 & 74.808 & 0.057 & 73.011 & 0.034 & 72.337 & 0.061 & 71.994 & -0.018 & 75.556 \\
\hline \multirow[t]{2}{*}{ Female } & \multicolumn{2}{|c|}{ Female $<20$} & \multicolumn{2}{|c|}{ Female 21-30 } & \multicolumn{2}{|c|}{ Female 31-40 } & \multicolumn{2}{|c|}{ Female 41-50 } & \multicolumn{2}{|c|}{ Female 51-60 } & \multicolumn{2}{|c|}{ Female $>60$} \\
\hline & I & $\mathrm{P}$ & I & $\mathrm{P}$ & I & $\mathrm{P}$ & I & $\mathrm{P}$ & I & $\mathrm{P}$ & I & $\mathrm{P}$ \\
\hline Ambient Condition & 0.309 & 83.519 & 0.361 & 79.562 & 0.286 & 77.434 & 0.304 & 76.699 & 0.277 & 74.542 & 0.365 & 78.295 \\
\hline Facility Design & 0.124 & 79.865 & -0.020 & 77.393 & 0.072 & 76.187 & 0.139 & 76.520 & 0.040 & 76.632 & -0.149 & 79.046 \\
\hline Facility Layout & 0.054 & 76.542 & 0.231 & 71.142 & 0.307 & 72.220 & 0.142 & 74.070 & 0.203 & 72.865 & 0.038 & 79.310 \\
\hline Equipment/Facility Condition & 0.227 & 80.538 & 0.336 & 74.149 & 0.219 & 72.156 & 0.323 & 71.195 & 0.317 & 70.522 & 0.403 & 75.622 \\
\hline Signage & 0.208 & 79.821 & 0.095 & 77.759 & 0.087 & 76.945 & 0.064 & 76.340 & 0.066 & 75.964 & 0.017 & 80.978 \\
\hline Facility System & 0.098 & 80.969 & -0.021 & 76.536 & 0.082 & 73.634 & 0.030 & 73.468 & 0.132 & 71.903 & 0.200 & 78.412 \\
\hline
\end{tabular}

I: Importance; P: Performance. 


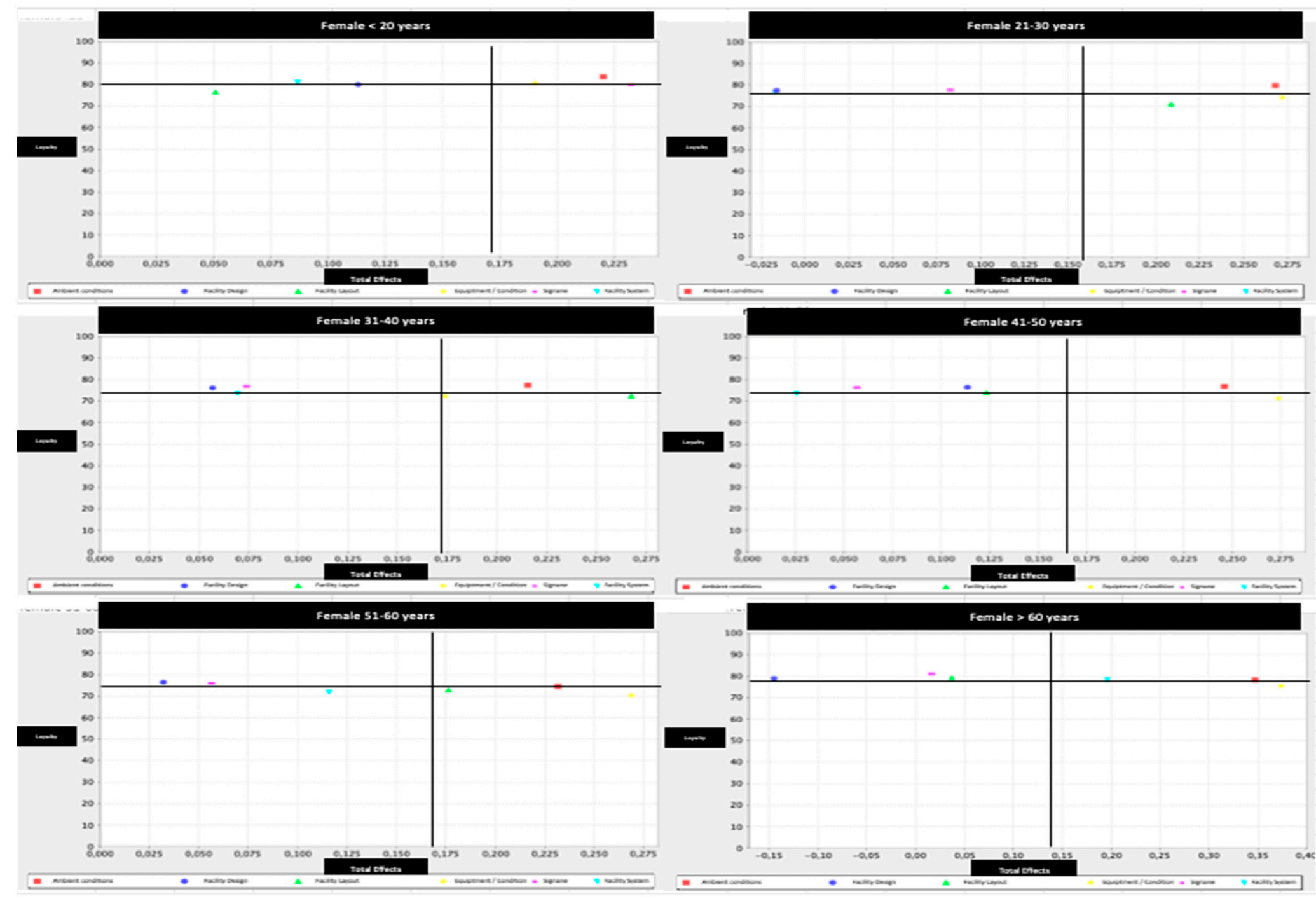

Figure 4. Importance-performance map by female and age group. Note: Red: ambient condition; Strong blue: facility design; Green: facility layout; Yellow: equipment/facility condition; Pink: signage; Light blue: facility system. 


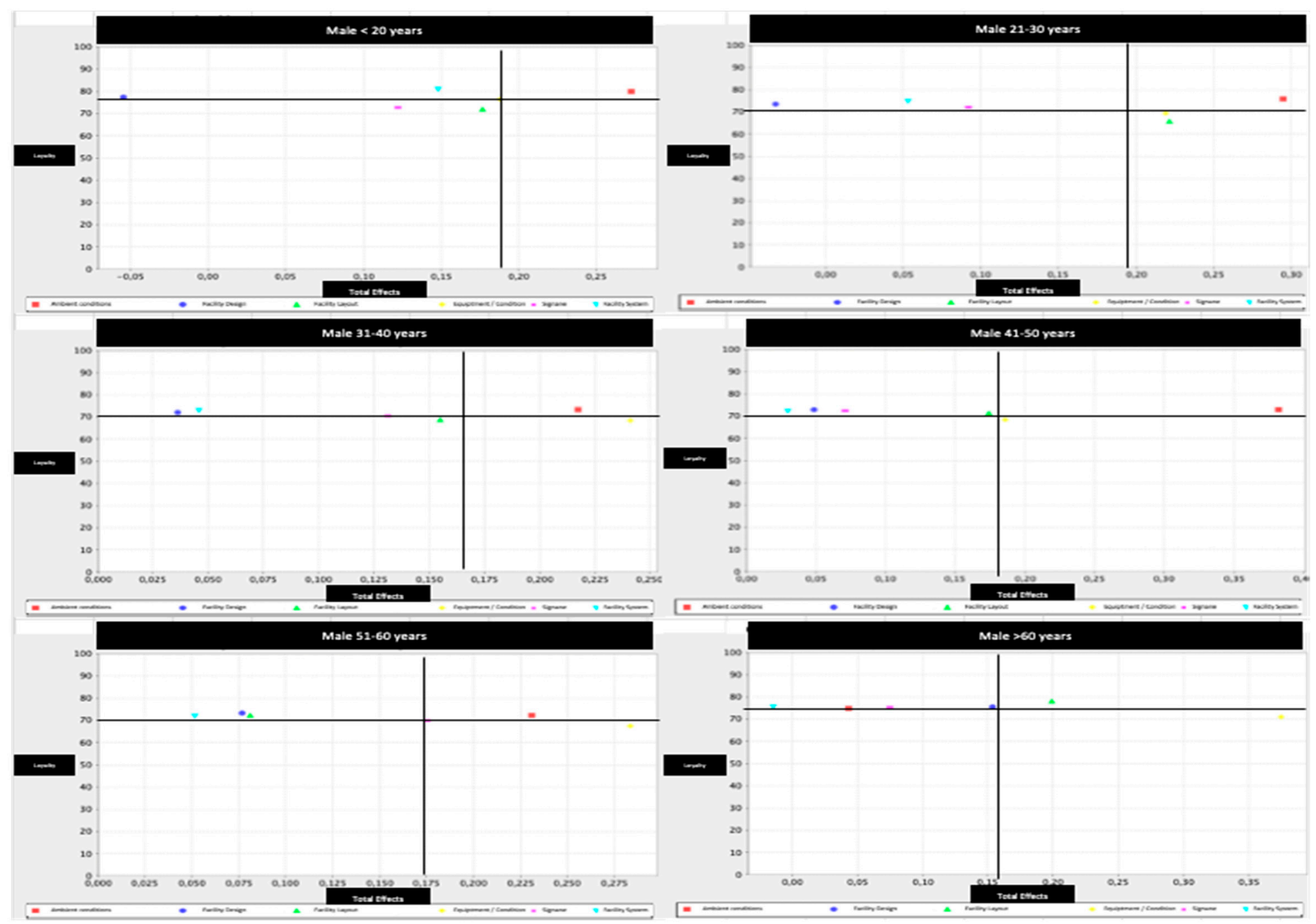

Figure 5. Importance-performance map by male and age group. Note: Red: ambient condition; Strong blue: facility design; Green: facility layout; Yellow: equipment/facility condition; Pink: signage; Light blue: facility system. 


\section{Discussion}

This study analyzed, through the IPMA, the effects of servicescape on customer loyalty in fitness centers. In particular, six aspects were analyzed based on the study by Kim et al. (2016): the ambient conditions, the facility design, the facility layout, the equipment and facility condition, the signages, and the facility system [9]. These factors were in turn related to gender and age to identify what the aspects to be improved were according to the servicescape and sociodemographic variables.

As has been revealed, IPMA is based on standardized regression coefficients (importance) and adds an additional dimension to the analysis that considers the values of the predictor variables, expressed here in terms of a scaled performance index from 0 to 100. The findings have shown the total effect of the independent variables of servicescape on consumer loyalty, calculated together with a scale of latent scores from 0 to 100 . These results will add value to those responsible for fitness centers in making decisions to improve customer loyalty [13]. Therefore, our findings confirm previous studies from different sectors that showed that servicescape has a positive relationship with consumer loyalty $[29,30,32]$. In fact, this research aligns Ong and Yap's (2017) study in which it was indicated that servicescape had a positive influence on consumers behavioral intentions in fitness centers [8]. However, these authors analyzed the relationship between both variables through four dimensions of servicescape, and the present study has confirmed the positive relationship through six dimensions. In turn, both studies differ by the samples used, having worked in this study with a very high sample of consumers from fitness centers, and analyzing the relationships between servicescape and loyalty through PLS-SEM.

In general terms, having carried out the IPMA the results showed that ambient conditions are the most valuable variable to increase the loyalty of consumers in fitness centers. Precisely, this aspect would be related to music [79], the colors used and the noise level [80], or cleanliness as suggested by Kim et al. (2016) [9] and León-Quismondo et al. (2020) [81]. This fact coincides with the works of Vilnai-Yavetz and Gilboa (2010), Bester (2012), and the study by Lee and Kim (2014) who concluded that a neglected environmental environment could decisively negatively influence a consumer's loyalty [82-84]. However, since the ambient condition already has a high performance index value, there is a low potential for further increase. The best option in terms of the importance and performance ratio seems to be the equipment and facility conditions and the facility layout. In fact, an improvement in the quality of the equipment, the maintenance of the fitness equipment and the own perception of safety of the sports equipment should be favored. Likewise, these results show the need to work on procedures to minimize waiting times in sports services, in turn influencing the design of spaces differentiated by activity levels. Similarly, it was observed that, of all the dimensions analyzed, the facility system versus the facility design were the aspects of minor importance for the sample in general. Specifically, it must be borne in mind that these factors referred to lighting levels, temperature, interior design, decoration, or the correct operation of the heating or air conditioning system.

Regarding the findings on servicescape and the variables of gender and age, the results have shown different aspects to consider to influence the loyalty of sports consumers. This fact is extremely important since authors such as Bernal-García et al. (2018) have already highlighted the need to analyze predictive variables of fidelity in sports consumers according to gender and age [11]. Precisely, men have shown a greater number of aspects where performance indexes can be better and therefore consumer loyalty can be improved. These results corroborate previous studies where women's perceptions have been more positive in sports services [40,41], although there are also works that indicate the opposite [12]. In fact, in relation to ambient conditions, such as the use of music that is pleasant and adapted to physical activity or the noise level being tolerable, this is a relevant factor for women and men of all the age groups, as concluded by Lee et al. (2019) [30]. Nonetheless, performance indices indicated that there is room for improvement for women aged 51 to 60 , and men aged 41 to 60 . In this sense, authors such as Bitner (1992) and Chang (2016) reinforce that stimulating environments could favor a positive approach toward the service that in this case would be the fitness center $[7,27]$. 
Regarding the facility design, authors such as Whitfield et al. (2014) and Ong and Yap (2017) pointed out the importance of infrastructure and facilities environments to create loyalty in their clients $[8,85]$. However, this study has shown that it is an aspect of low importance in men and women for consumer loyalty in fitness centers. In turn, the results have shown that the facility layout is possibly the second factor with the greatest margin for improvement in both women and men. This situation is accentuated in men, since the performance indices are below the horizontal axis in the IPMA [76] at ages below 50 years. As for women, the same situation occurs, with the exception of the age groups of under 20, between 41 and 50, and over 60, where this factor is not relevant for fidelity. As stated by Ong and Yap (2017), those responsible for fitness centers should improve functionality and sports spaces for greater consumer comfort [8].

Regarding the equipment and the facility condition, the findings have shown that it is the factor with the greatest margin for improvement in both men and women. In fact, with the exception of women under 20 years of age who are in Q1, all the other age groups are in Q2 [76] and therefore should be improved due to their relationship with consumer loyalty. This fact shows that performance indices, and hence the loyalty of the sports consumer, can be improved. Thus, the results have shown its importance as already indicated by Kim et al. (2016) and Lee et al. (2019) [9,30], in this way influencing the good conditions of the sports facility [8].

This study has also shown the differences between men and women according to the signage factor. Hence, with the exception of women under 20 years of age where it does have a strong influence on fidelity, in the other age groups of women it does not matter. Regarding men, the findings showed margins of improvement in performance indices for men younger than 40 and those between 51 and 60 years old. These results differ from those achieved in fitness centers by Lee et al. (2019) and Ong and Yap (2017) [8,30], who concluded their high need for greater fidelity, as evidenced in other sectors [86].

Regarding the last factor (facility system), the findings showed that only women over 50 are in Q1 [76]. This fact corroborates the results of León-Quismondo et al. (2020) where women, unlike men, do give importance to this [12]. All in all, authors such as Lee et al. (2019) point out that although this factor may not be fundamental to create loyalty in consumers [30], it could at least serve to create a feeling of good service in them and be able to differentiate the centers from the competition.

As to the limitations of the study, this work has been based on the servicescape scale proposed by Kim et al. (2016) that, although it is specific to fitness centers [9], could have deficiencies in relation to decisive factors in consumer perception. Likewise, fidelity was obtained through the behavioral intentions of consumers, which therefore influence subjective behavior. This fact means that the real behavior of consumers could have been modified if objective loyalty variables had been considered [38]. Similarly, having used the IPMA in sports services results in a low comparison with other articles due to the novelty of the analysis, even though it has been used in other sectors. Based on these limitations, the use of other scales and factors that analyze servicescape in sports facilities and which, in turn, is analyzed in different sports spaces, are proposed as future lines of research. Likewise, it is necessary to use objective behavioral variables in future investigations to identify aspects that could influence consumer loyalty. Finally, other researchers are urged to use IPMA for a better understanding of aspects that could be evaluated and improved by managers, in favor of sports consumers' greater loyalty.

\section{Practical Implications}

The study is almost certainly the largest sample carried out on servicescape in fitness centers. Its results are very interesting and can be extrapolated when it comes to proposing strategies about servicescape in fitness centers. In fact, although the results have shown differences in terms of gender and age, it is proposed to focus efforts on facility layout, equipment, and facility conditions. Specifically, it is recommended that managers improve the perception of the equipment's functionality, and the perception of waiting times (such as the enrollment process, attention to prescribe a training program, or any specific customer service process). Another aspect to improve is the feeling of spaciousness in sports spaces. In fact, due to the post-Covid-19 situation, this aspect could recently have been 
improved due to the increase in the distance between the sports equipment, which would provide a greater sense of spaciousness. Finally, the managers of the fitness centers should also focus their efforts on the continuous maintenance of the equipment as well as safety strategies for sports consumers.

\section{Conclusions}

The objective of this study was to analyze the relationship between servicescape and the loyalty of fitness center consumers, this being examined by gender and age with the IPMA. In this sense, the results of this research show interesting results in different lines. Our findings demonstrate the relationship between servicescape and loyalty in fitness centers consumers. The results have shown the high importance that consumers give to tangibility in fitness centers, from which the managers of the sports facilities must manage and adapt correctly.

In general, the aspects with room for improvement and affecting consumer loyalty in fitness centers were the equipment and the facility conditions, and the facility layout. In this sense, fitness centers must improve the safety, maintenance and quality of sports equipment. They must also get a better design of sports spaces with which consumers are more comfortable and perceive less waiting time to perform physical activities.

In relation to gender and age, the aspects which could be improved were to a greater extent the equipment and facility condition in women over 21 years old, and the facility layout for women between 21 to 40 years old and 51 to 60 years old. They also have room to improve the signage for women under 21 years of age. That is, the signage must be helpful. Regarding the perception of women over 51 years of age, ambient conditions such as cleanliness, noise or the environment could also have room for improvement. Regarding men, the aspects with the highest performance margins were the equipment and facility conditions in all the age groups, the facility layout in men from 21 to 30 years, and the signage in men from 51 to 60 years. In conclusion, there is still room for increasing consumer loyalty through aspects related to servicescape.

Author Contributions: J.G.-F. and G.C.-C. designed the study; J.F.-G. and P.G.-R. administered and oversaw the study; G.C.-C. and J.G.-F. interpreted the data; P.G.-R., A.J.S.-O., and M.G.-P. drafted the manuscript; J.F.-G. and A.J.S.-O. reviewed and edited the manuscript. All authors have read and agreed to the published version of the manuscript.

Funding: The authors are thankful to the Spanish Ministry of Economy and Competitiveness for the financial support provided through the project ECO2017-88499-P (MINECO/AEI/FEDER, UE).

Conflicts of Interest: The authors declare no conflict of interest.

\section{References}

1. Foroughi, B.; Iranmanesh, M.; Gholipour, H.F.; Hyun, S.S. Examining relationships among process quality, outcome quality, delight, satisfaction and behavioural intentions in fitness centres in Malaysia. Int. J. Sport. Mark. Spons. 2019, 20, 374-389. [CrossRef]

2. The 2019 IHRSA Global Report IHRSA. Available online: https://www.ihrsa.org/publications/the-2019-ihrsaglobal-report/ (accessed on 17 July 2020).

3. Europe Active. European Health \& Fitness Market: Report Deloitte 2020. Available online: https://blackboxpublishers.com/en/publications/european-health-fitness-market-report-ehfmr-2020e-book/?fbclid=IwAR2hbI6a74BT73TyiDnGrgFs893TXUS0yiG23mUKgsIyPDj58bUCy67EizY (accessed on 17 July 2020).

4. Cepeda-Carrión, I.; Cepeda-Carrión, G. How public sport centers can improve the sport consumer experience. Int. J. Sport. Mark. Spons. 2018, 19, 350-367. [CrossRef]

5. García-Fernández, J. Customer Loyalty in Spanish Private Fitness Centers: The Value Creation and Perception Chain. Ph.D. Thesis, Universidad de Sevilla, Sevilla, Spain, 2012.

6. Han, J.; Kang, H.J.; Kwon, G.H. A systematic underpinning and framing of the servicescape: Reflections on future challenges in healthcare services. Int. J. Environ. Res. Public Health 2018, 15, 509. [CrossRef] [PubMed] 
7. Bitner, M.J. Servicescapes: The Impact of Physical Surroundings on Customers and Employees. J. Mark. 1992, 56, 57-71. [CrossRef]

8. Ong, D.L.T.; Yap, W.X. The Impact of Fitness Center Servicescape on Individual Behavior: The Mediating Role of Emotional Response. J. Glob. Sport Manag. 2017, 2, 128-142. [CrossRef]

9. Kim, K.T.; Bae, J.; Kim, J.-C.; Lee, S. The Servicescape in the Fitness Center: Measuring Fitness Center's Services. Int. J. Sport Manag. Recreat. Tour. 2016, 21, 1-20. [CrossRef]

10. Harris, L.C.; Ezeh, C. Servicescape and loyalty intentions: An empirical investigation. Eur. J. Mark. 2008, 42, 390-422. [CrossRef]

11. Bernal-García, A.; García-Fernández, J.; Grao-Cruces, A.; Teva-Vilén, R.; Nuviala-Nuviala, A. Behavioral intentions of sports services consumers according to the social and demographic variables. Rev. Mex. Psicol. 2018, 35, 63-71.

12. León-Quismondo, J.; García-Unanue, J.; Burillo, P. Service perceptions in fitness centers: IPA approach by gender and age. Int. J. Environ. Res. Public Health 2020, 17, 2844. [CrossRef]

13. Ringle, C.M.; Sarstedt, M. Gain more insight from your PLS-SEM results the importance-performance map analysis. Ind. Manag. Data Syst. 2016, 116, 1865-1886. [CrossRef]

14. Martilla, J.A.; James, J.C. Importance-Performance Analysis. J. Mark. 1977, 41, 77-79. [CrossRef]

15. Cortes-Navas, S.L.; Rojas-Berrio, S. Evolution of the Servicescape concept: Systematic review of literature 1995-2017. Espacios 2018, 39, 6.

16. Hightower, R., Jr.; Shariat, M. Servicescape's hierarchical factor structure model. Glob. Rev. Bus. Econ. Res. 2009, 5, 375-398.

17. Parish, J.T.; Berry, L.L.; Lam, S.Y. The effect of the servicescape on service workers. J. Serv. Res. 2008, 10, 220-238. [CrossRef]

18. Siddiqui, M.H.; Tripathi, S.N. Application of soft operations research for enhancing the servicescape as a facilitator. Vikalpa 2011, 36, 33-50. [CrossRef]

19. Hoffman, K.D.; Kelley, S.W.; Chung, B.C. A CIT investigation of servicescape failures and associated recovery strategies. J. Serv. Mark. 2003, 17, 322-340. [CrossRef]

20. Hul, M.K.; Dube, L.; Chebat, J.C. The impact of music on consumers' reactions to waiting for services. J. Retail. 1997, 73, 87-104. [CrossRef]

21. Lee, S. Evaluating serviceability of healthcare servicescapes: Service design perspective. Int. J. Des. 2011, 5, 61-71.

22. Cockrill, A.; Goode, M.; Emberson, D. Servicescape matters-Or does it? The special case of betting shops. Mark. Intell. Plan. 2008, 26, 189. [CrossRef]

23. Johnson, L.; Mayer, K.; Champaner, E. Casino Atmospherics from a Customer's Perspective: A Re-Examination. UNLV Gaming Res. Rev. J. 2004, 8, 1 .

24. Conelius, H.; Van, H.; Yolandi, B.; Elmien, D. The relationship between atmospherics, servicescape and destination attractiveness of a holiday destination. Innov. Mark. 2009, 5, 55-65.

25. Lambrecht, K.; Kaefer, F.; Ramenofsky, S. Sportscape Factors Influencing Spectator Attendance and Satisfaction at a Professional Golf Association Tournament. Sport Mark. Q. 2009, 18, 165.

26. Fernandes, T.; Neves, $\mathrm{S}$. The role of servicescape as a driver of customer value in experience-centric service organizations: The Dragon Football Stadium case. J. Strateg. Mark. 2014, 22, 548-560. [CrossRef]

27. Chang, K.C. Effect of servicescape on customer behavioral intentions: Moderating roles of service climate and employee engagement. Int. J. Hosp. Manag. 2016, 53, 116-128. [CrossRef]

28. Madzharov, A.V.; Block, L.G.; Morrin, M. The cool scent of power: Effects of ambient scent on consumer preferences and choice behavior. J. Mark. 2015, 79, 83-96. [CrossRef]

29. Tran, Q.X.; Van Dang, M.; Tournois, N. The role of servicescape and social interaction toward customer service experience in coffee stores. The case of Vietnam. Int. J. Cult. Tour. Hosp. Res. 2020. [CrossRef]

30. Lee, T.H.; Fu, C.J.; Tsai, L.F. How servicescape and service experience affect loyalty: Evidence from attendees at the Taipei International Travel Fair. J. Conv. Event Tour. 2019, 20, 398-420. [CrossRef]

31. Rai, A.K.; Anirvinna, C. Investigating the influence of servicescape on customer loyalty at a fine-dining restaurants in Jaipur. Afr. J. Hosp. Tour. Leis. 2019, 8, 1-9.

32. Hightower, R.; Brady, M.K.; Baker, T.L. Investigating the role of the physical environment in hedonic service consumption: An exploratory study of sporting events. J. Bus. Res. 2002, 55, 697-707. [CrossRef] 
33. Yacout, O.M. Service Quality, Relational Benefits, and Customer Loyalty in a Non-Western Context. SAM Adv. Manag. J. 2010, 75, 4.

34. Baena-Arroyo, M.J.; García-Fernández, J.; Gálvez-Ruiz, P.; Grimaldi-Puyana, M. Analyzing consumer loyalty through service experience and service convenience: Differences between instructor fitness classes and virtual fitness classes. Sustainability 2020, 12, 828. [CrossRef]

35. García-Fernández, J.; Gálvez-Ruíz, P.; Fernández-Gavira, J.; Vélez-Colón, L.; Pitts, B.; Bernal-García, A. The effects of service convenience and perceived quality on perceived value, satisfaction and loyalty in low-cost fitness centers. Sport Manag. Rev. 2018, 21, 250-262. [CrossRef]

36. García-Fernández, J.; Gálvez-Ruiz, P.; Sánchez-Oliver, A.J.; Fernández-Gavira, J.; Pitts, B.G.; Grimaldi-Puyana, M. An analysis of new social fitness activities: Loyalty in female and male CrossFit users. Sport Soc. 2020, 23, 204-221. [CrossRef]

37. Baena-Arroyo, M.J.; Gálvez-Ruiz, P.; Sánchez-Oliver, A.J.; Bernal-García, A. The relationship among service experience, perceived value and behavioural intentions of customers in a group fitness class. Rev. Psicol. Deport. 2016, 25, 89-92.

38. García-Fernández, J.; Gálvez-Ruiz, P.; Vélez-Colon, L. Client profile of Spanish fitness centers: Segmentation by loyalty and characteristics of the client. In Sports Management as an Emerging Economic Activity: Trends and Best Practices; Peris-Ortiz, M., Álvarez-García, J., del Río-Rama, M., de la Cruz, Eds.; Springer International Publishing: Cham, Switzerland, 2017; pp. 273-291.

39. García-Fernández, J.; Sánchez-Oliver, A.J.; Grimaldi-Puyana, M.; Fernández-Gavira, J.; Gálvez-Ruíz, P. Quality and customer loyalty: A segmentation analysis in low-cost fitness centers. Rev. Psicol. Deport. 2017, 26, 17-22.

40. García-Fernández, J.; Fernández-Gavira, J.; Bernal-García, A. La percepción de calidad y fidelidad en clientes de centros de fitness low cost. Suma Psicol. 2014, 21, 123-130. [CrossRef]

41. García-Fernández, J.; Cepeda-Carrion, G.; Martínez-Ruíz, D. La satisfacción de clientes y su relación con la percepción de calidad en Centro de Fitness: Utilización de la escala CALIDFIT. Rev. Psicol. Deport. 2012, 21, 309-319.

42. García-Fernández, J.; Bernal-García, A.; Lara, A.; Galán, P. La calidad percibida de servicio y su influencia en la fidelidad de usuarios mayores en centros de fitness públicos. Escr. Psicol. 2013, 6, 26-34. [CrossRef]

43. Nuviala, A.; Grao-Cruces, A.; Pérez-Turpin, J.A.; Nuviala, R. Perceived service quality, perceived value and satisfaction in groups of users of sports organizations in Spain. Kinesiology 2012, 44, 94-103.

44. Nuviala, R.; Teva, M.R.; Pérez, R.; Grao, A.; Tamayo, J.A.; Nuviala, A.; Teva, R.; Pérez-Ordás, R.; Grao-Cruces, A.; Tamayo, J.A.; et al. Segmentación de usuarios de servicios deportivos. Retos Nuevas Tend. Educ. Física Deport. Recreación 2014, 25, 90-94.

45. Yu, H.S.; Zhang, J.J.; Kim, D.H.; Chen, K.K.; Henderson, C.; Min, S.D.; Huang, H. Service Quality, Perceived Value, Customer Satisfaction, and Behavioral Intention Among Fitness Center Members Aged 60 Years and Over. Soc. Behav. Personal. Int. J. 2014, 42, 757-767. [CrossRef]

46. Gu, M.O.; Eun, Y. Health-promoting behaviors of older adults compared to young and middle-aged adults in Korea. J. Gerontol. Nurs. 2002, 28, 46-56. [CrossRef] [PubMed]

47. Mullen, S.P.; Whaley, D.E. Age, gender, and fitness club membership: Factors related to initial involvement and sustained participation. Int. J. Sport Exerc. Psychol. 2010, 8, 24-35. [CrossRef]

48. Humpel, N.; Owen, N.; Leslie, E. Environmental factors associated with adults' participation in physical activity. A review. Am. J. Prev. Med. 2002, 22, 188-199. [CrossRef]

49. Clemes, M.D.; Brush, G.J.; Collins, M.J. Analysing the professional sport experience: A hierarchical approach. Sport Manag. Rev. 2011, 14, 370-388. [CrossRef]

50. Arias-Ramos, M.; Serrano-Gómez, V.; García-García, Ó. ¿Existen diferencias en la calidad percibida y satisfacción del usuario que asiste a un centro deportivo de titularidad privada o pública? Un estudio piloto. Cuad. Psicol. Deport. 2016, 16, 99-110.

51. Zamorano-Solís, S.; García Fernández, J. El análisis importancia-valoración según género y permanencia: El caso de los centros de fitness. Mater. Hist. Deport. 2018, 16, 24-35.

52. Martínez-García, J.A. The consideration of the propagation of errors for the importance-performance analysis in sports management. Cuad. Psicol. Deport. 2018, 18, 141-149.

53. Sever, I. Importance-performance analysis: A valid management tool? Tour. Manag. 2015, 48, 43-53. [CrossRef]

54. Wyród-Wróbel, J.; Biesok, G. Decision making on various approaches to Importance-Performance Analysis (IPA). Eur. J. Bus. Sci. Technol. 2017, 3, 123-131. [CrossRef] 
55. Tailab, M.M.K. Using Importance-Performance Matrix Analysis to Evaluate the Financial Performance of American Banks during the Financial Crisis. SAGE Open 2020, 10, 2158244020902079. [CrossRef]

56. Ting, S.H.; Yahya, S.; Tan, C.L. Importance-Performance Matrix Analysis of the Researcher's Competence in the Formation of University-Industry Collaboration Using Smart PLS. Public Organ. Rev. 2020, 20, 249-275. [CrossRef]

57. Ebrahimi, P.; Hajmohammadi, A.; Khajeheian, D. Place branding and moderating role of social media. Curr. Issues Tour. 2020, 23, 1723-1731. [CrossRef]

58. Wook, M.; Ismail, S.; Yusop, N.M.M.; Ahmad, S.R.; Ahmad, A. Identifying priority antecedents of educational data mining acceptance using importance-performance matrix analysis. Educ. Inf. Technol. 2019, 24, 1741-1752. [CrossRef]

59. Groß, M. Heterogeneity in consumers' mobile shopping acceptance: A finite mixture partial least squares modelling approach for exploring and characterising different shopper segments. J. Retail. Consum. Serv. 2018, 40, 8-18. [CrossRef]

60. Palos-Sanchez, P.; Martin-Velicia, F.; Saura, J.R. Complexity in the acceptance of sustainable search engines on the internet: An analysis of unobserved heterogeneity with FiMix-PLS. Complexity 2018, 6561417, 1-19. [CrossRef]

61. Carranza, R.; Díaz, E.; Martín-Consuegra, D. The influence of quality on satisfaction and customer loyalty with an importance-performance map analysis Exploring the mediating role of trust. J. Hosp. Tour. Technol. 2018, 9, 380-396.

62. Reyes-Menendez, A.; Palos-Sanchez, P.R.; Saura, J.R.; Martin-Velicia, F. Understanding the Influence of Wireless Communications and Wi-Fi Access on Customer Loyalty: A Behavioral Model System. Wirel. Commun. Mob. Comput. 2018, 3487398, 1-16. [CrossRef]

63. Ramayah, T.; Chiun, L.M.; Rouibah, K.; May, O.S. Identifying Priority Using an Importance-Performance Matrix Analysis (IPMA): The Case of Internet Banking in Malaysia. Int. J. E-Adopt. 2014, 6, 1-15. [CrossRef]

64. Rigdon, E.E.; Ringle, C.M.; Sarstedt, M.; Gudergan, S.P. Assessing heterogeneity in customer satisfaction studies: Across industry similarities and within industry differences. Adv. Int. Mark. 2011, 22, 169-194.

65. Streukens, S.; Leroi-Werelds, S.; Willems, K. Dealing with nonlinearity in importance-performance map analysis (IPMA): An integrative framework in a PLS-SEM context. In Partial Least Squares Path Modeling: Basic Concepts, Methodological Issues and Applications; Springer: Cham, Switzerland, 2017; ISBN 9783319640693.

66. Zeithaml, V.A.; Berry, L.L.; Parasuraman, A. The behavioral consequences of service quality. J. Mark. 1996, 60, 31-46. [CrossRef]

67. Martín-Consuegra, D.; Gómez, M.; Molina, A. Consumer sensitivity analysis in mobile commerce advertising. Soc. Behav. Pers. 2015, 43, 883-897. [CrossRef]

68. Valcarce, M.; López, F.; García-Fernández, J. $6^{\circ}$ Informe Gimnasios Low Cost España 2018. Available online: https://valgo.es/tienda/6o-informe-gimnasios-low-cost-espana-2018/ (accessed on 23 June 2020).

69. Rigdon, E.E. Partial Least Squares Path Modeling. In Structural Equation Modeling: A Second Course; Research Methods and Philosophy: Milan, Italy, 2013; pp. 81-116.

70. Henseler, J. Bridging Design and Behavioral Research with Variance-Based Structural Equation Modeling. J. Advert. 2017, 46, 1-15. [CrossRef]

71. Cepeda-Carrión, G.; Cegarra-Navarro, J.G.; Cillo, V. Tips to use partial least squares structural equation modelling (PLS-SEM) in knowledge management. J. Knowl. Manag. 2019, 23, 67-89. [CrossRef]

72. Ringle, C.M.; Wende, S.; Becker, J.-M. SmartPLS 3. 2015, Boenningstedt: SmartPLS GmbH. Available online: http://www.smartpls.com (accessed on 5 June 2020).

73. Hair, J.F.; Sarstedt, M.; Hopkins, L.; Kuppelwieser, V.G. Partial least squares structural equation modeling (PLS-SEM): An emerging tool in business research. Eur. Bus. Rev. 2014, 26, 106. [CrossRef]

74. Chin, W.W. The Partial Least Squares approach to Structural Equation Modeling. Mod. Methods Bus. Res. 1998, 295, 295-336.

75. Kock, N.; Lynn, S.G. Lateral Collinearity and Misleading Results in Variance-Based SEM: An Illustration and Recommendations. J. Assoc. Inf. Syst. 2012, 13, 546-580. [CrossRef]

76. Hair, J.F., Jr.; Hult, G.T.M.; Ringle, C.M.; Sarstedt, M.; Castillo Apraiz, J.; Cepeda Carrión, G.A.; Roldán, J.L. Manual de Partial Least Squares Structural Equation Modeling (PLS-SEM) (Segunda Edición); OmniaScience (Sage Publications): Barcelona, Spain, 2019; ISBN 978-84-947996-2-4.

77. Henseler, J.; Hubona, G.; Ray, P.A. Using PLS path modeling in new technology research: Updated guidelines. Ind. Manag. Data Syst. 2016, 116, 2-20. [CrossRef] 
78. Henseler, J.; Ringle, C.M.; Sarstedt, M. A new criterion for assessing discriminant validity in variance-based structural equation modeling. J. Acad. Mark. Sci. 2014, 43, 115-135. [CrossRef]

79. Suwono, L.V.; Sihombing, S.O. Factors Affecting Customer Loyalty of Fitness Centers: An Empirical Study. J. Din. Manaj. 2016, 7, 45-55. [CrossRef]

80. Bhasin, H. Servicescape: Meaning, Examples, Elements, Approach, and Roles. Available online: https: //www.marketing91.com/servicescape/ (accessed on 17 July 2020).

81. León-Quismondo, J.; García-Unanue, J.; Burillo, P. Best practices for fitness center business sustainability: A qualitative vision. Sustainability 2020, 12, 5067. [CrossRef]

82. Vilnai-Yavetz, I.; Gilboa, S. The Effect of Servicescape Cleanliness on Customer Reactions. Serv. Mark. Q. 2010, 31, 213-234. [CrossRef]

83. Bester, P. The business environment of sport organisations: A review. Afr. J. Bus. Manag. 2012, 6, 11530-11535.

84. Lee, S.Y.; Kim, J.H. Effects of servicescape on perceived service quality, satisfaction and behavioral outcomes in public service facilities. J. Asian Archit. Build. Eng. 2014, 13, 125-131. [CrossRef]

85. Whitfield, J.; Dioko, L.D.A.N.; Webber, D.; Zhang, L. Attracting convention and exhibition attendance to complex MICE venues: Emerging data from Macao. Int. J. Tour. Res. 2014, 16, 169-179. [CrossRef]

86. Siu, N.Y.M.; Wan, P.Y.K.; Dong, P. The impact of the servicescape on the desire to stay in convention and exhibition centers: The case of Macao. Int. J. Hosp. Manag. 2012, 31, 236-246. [CrossRef]

(C) 2020 by the authors. Licensee MDPI, Basel, Switzerland. This article is an open access article distributed under the terms and conditions of the Creative Commons Attribution (CC BY) license (http://creativecommons.org/licenses/by/4.0/). 